\title{
Metanarrative Autofiction: Critical Engagement with Cultural Narrative Models
}

\author{
Hanna Meretoja
}

While the view that narrative is integral to humans' mode of making sense of the world has shaped the "narrative turn" in the humanities and social sciences since the 1980s (Ricœur 1983; Hyvärinen 2008; Meretoja 2014), in the twenty-first century society more broadly has become obsessed with narratives (see Polletta 2006; Salmon 2010; Fernandes 2017; Mäkelä \& Meretoja 2022). The notion of finding one's own narrative has pervaded culture at large, and it has been put to extensive commercial use. Contemporary fiction is increasingly responding to this trend by critically reflecting on how cultural narrative models shape our lives. While metafiction (Hutcheon 1980; Waugh 1984; Currie 2014) was a key characteristic of postmodernist literature and art, an important form of self-reflexivity in contemporary literary fiction is "metanarrativity" - self-aware reflection not only on the narratives' own narrativity but also on cultural processes of narrative sense-making and on the roles that narrative practices play in our lives. This is particularly salient in autofictional writing, which centers

H. Meretoja $(\bowtie)$

University of Turku, Turku, Finland e-mail: hailme@utu.fi

(C) The Author(s) 2022

A. Effe, H. Lawlor (eds.), The Autofictional, Palgrave Studies in Life Writing, https://doi.org/10.1007/978-3-030-78440-9_7 
on the relationship between the real and the imaginary, life and its narrativization. ${ }^{1}$

To date, metanarratives have been studied from two different perspectives. First, the term "metanarrative" is used in critical theory, particularly in connection to postmodernism, predominantly with reference to what Jean-François Lyotard (1979) called “grand narratives” (grands récits) master narratives that seek to offer legitimation through the anticipated completion of a master idea (such as narratives of Marxism and the Enlightenment). It is misleading, however, to call Lyotardian master narratives "metanarratives" because the prefix "meta-" suggests that they are narratives about narratives. Master narratives, in contrast, mask their own narrativity. Second, metanarrativity (or metanarrative commentary) is a narratological term for self-reflexive narration in which the narrators reflect on their own process of narration (see, e.g., Fludernik 1996, 2003; Neumann and Nünning 2014; Macrae 2019).

These approaches leave out two central dimensions of self-reflexive storytelling: metanarrative fiction is characterized by critical reflection on, first, the significance of cultural narratives for individuals and communities and, second, the functions of narratives in our lives. In this chapter, I explore how what I call "metanarrative autofiction" makes narrative its theme through critical engagement with cultural narrative models of sense-making. While metafictional autofiction focuses on issues of fictionality in narrating lives, metanarrative autofiction, as I define it, reflects on the role of narratives (both fictional and nonfictional) in the processes in which we make sense of our lives. My notion is thus also different from what one might call metanarrative autobiography—a term that Bianca Theisen uses for autobiographical texts that highlight the "codes that have governed the writing of autobiographies" $(2003,11)$, and which could logically also be used to designate autobiographical texts reflecting on the act of narration in general, as well as those reflecting on cultural narrative templates. Metanarrative autofiction, in distinction from metanarrative autobiography, focuses in addition on the relation between the real and the imaginary, as is characteristic of autofiction in general, and often employs experimental narrative strategies in the process. In particular, I analyze the affordances of metanarrative autofiction by focusing on how it deals with the nature and conditions of narrative agency.

The notion of narrative agency has been used to foreground the role of narrative self-interpretation in bringing about the "integration of the self over time" - a process that is "dynamic, provisional and open to change 
and revision" (Mackenzie 2008, 11-12). However, I have argued (Meretoja 2018, 11-12) that the narrative dimension of agency is not merely at play in processes of self-interpretation, but forms, more broadly, a constitutive aspect of our agency as we participate, through our actions and inactions, in narrative practices that perpetuate and challenge social structures. The concept of narrative agency signals that culturally mediated narrative interpretations play an important role in constituting us as subjects capable of action, while simultaneously alerting us to how narrative agency is socially conditioned. Our narrative agency means our ability to navigate our narrative environments: use and engage with narratives that are culturally available to us, to analyze and challenge them, and to practice agential choice over which narratives we use and how we narratively interpret our lives and the world around us. Narrative agency can be amplified or diminished, and agentic power is unevenly distributed both within societies and across the globe. Amplified narrative agency can manifest itself, for example, as enhanced awareness of one's possibilities of action, affect, and thought in relation to one's narrative environments and as the ability to imagine different modes of living a fulfilling life.

I take narrative agency to include three central dimensions. First, it involves narrative awareness: awareness of different narrative perspectives and of the cultural repertoire of narratives that circulate in our cultural environments and provide us with models of sense-making. Second, it includes narrative imagination: the capacity to imagine beyond what appears to be self-evident in the present (see Andrews 2014; Brockmeier 2015) and to engage with the culturally available repertoire of narratives critically and creatively in ways that expand one's "sense of the possible" (Meretoja 2018, 20, 90-97). Its third aspect is narrative dialogicality: the capacity to enter into relationships and be part of communities that have their own shared "narrative in-betweens" (Meretoja 2018, 117-125), that is, intersubjective mythologies and narrative sense-making systems, and to participate in their renewal, challenging, and transformation.

An important strand of contemporary autofiction problematizes the pressure to create a single, coherent life story, articulating how the self is constituted in relation to narratives that are only partly our own, unearthing the normative aspects of the cultural narrative models that are imposed on us, and exploring alternatives to dominant models of how to live and narrate a fulfilling life. In this chapter, I will analyze three examples of such contemporary metanarrative autofiction, showing how the respective texts 
display and work through the three dimensions of narrative agency. I propose that in so doing they contribute to shaping narrative agency in our culture at large.

\section{Narrative, Memory, and Imagination in Ernaux's LES ANNÉES}

The form of Annie Ernaux's Les Années is highly experimental. It avoids the first-person singular pronoun and, instead, oscillates between the third-person singular (elle/she) and the first-person plural (nous/we). "Ernaux" the narrator refers to herself/the protagonist as "she" (elle) and to her generation or peer-group as "we" (nous). ${ }^{2}$ This impersonal autobiography charts the change of times through the itinerary of her own life, linking the unfolding of an individual life to historical events and change of fashions and mentalities. It compellingly entwines the personal and the collective by showing how the most personal experience takes place in a space shaped by collective forces and how major historical events are experienced differently by each individual. I will focus here on how Les Années thematizes the narrative aspect of memory and imagination.

Ernaux's autobiographical impulse seems to arise from a sense of the past disappearing. Aging and serious illness (breast cancer) prompt her to narrate her life and seek a fitting form for such an endeavor. ${ }^{3}$ The narrator feels that there is "something too permanent about 'I,' something shrunken and stifling, whereas 'she' is too exterior and remote" (2017, 169-170/2008, 187-188). ${ }^{4}$ Illness and aging produce a sense of transience and a felt need to leave a trace. Writing is about constructing and preserving a past in order to have a sense of the multitude of who one has been and who one is now and to see that process in relation to other people:

She doesn't know what she wants from these inventories, except maybe through the accumulation of memories of objects, to again become the person she was at such and such a time. She would like to assemble these multiple images of herself, separate and discordant, thread them together with the story of her existence, starting with her birth during World War II up until the present day. Therefore, an existence that is singular but also merged with the movements of a generation. (169/187)

"Ernaux" wants to remember, to take stock of her life, but with a keen awareness of how her personal memory is entwined with collective 
imagination. Even highly subjective bodily experience is mediated by cultural narrative models of sense-making:

She has mined her intuition of what her book's form will be from another sensation, the one that engulfs her when, starting with a frozen memoryimage of herself with other kids on a hospital bed after tonsil surgery, after the war, or crossing Paris on a bus in July of 1968, she seems to melt into an indistinct whole whose parts she manages to pull free, one at a time, through an effort of critical consciousness: elements of herself, customs, gestures, words, etc. [...] Then, in a state of profound, almost dazzling satisfaction, she finds something that the image from personal memory doesn't give her on its own: a kind of vast collective sensation that takes her consciousness, her entire being, into itself. (223-224/250)

Falling ill is an intensely personal experience, but Ernaux shows that it also has a collective dimension and is affected by cultural narratives of illness. How we think about cancer as disease, for example, is shaped by narratives of restitution and recovery that dominate the media. "Ernaux" mentions the illness almost in passing as a trivial thing that seems to affect all women of her generation:

a tumour of the kind that seems to burgeon in the breasts of all women her age, and appeared to her a normal occurrence, almost, because the things we most fear happen. At the same time she received the news that a baby was growing in the womb of her eldest son's partner-the ultrasound revealed a girl, and meanwhile she'd lost all her hair as a result of chemotherapy. This replacement of herself in the world, without delay, profoundly disturbed her. $(220 / 246)$

First, in terms of the three aspects of narrative agency, Les Années is permeated with narrative awareness. Each memory is recounted so that the personal and the collective intersect. Personal experiences are shown to take shape in a cultural context that functions as a "space of experience" (Koselleck 2004) that allows certain experiences and disallows others. Ernaux uses this Koselleckian concept when she speaks of "[ $t]$ he space of experience" that "lost its familiar contours" $(2017,170 / 2008,188)$. The narrator acknowledges that we not only share experience of great historical events ("our landmarks, 1968 and 1981" [170/188]) but "a great deal of shared experience that left no conscious trace" (180/200) and is linked to shared habits and assumptions. By articulating cultural narratives 
underlying such shared assumptions, Les Années brings elements of the narrative unconscious to the level of narrative awareness (see also Meretoja 2018, 18-21; Freeman 2010, 105, 120).

Narrative awareness also involves awareness of how people search for "models of existence in space and time" (108/118). Les Années depicts how people create their "personal Pantheon" (119/130), their personal mythology of figures they adore and from whom they seek guidance and inspiration. Literature and other arts as well as advertising provide narrative "models for how to live, behave, and furnish the home. It was society's cultural educator" (111/122). Ernaux disenchants the Pantheon of narrative models by showing how not only intellectual heroes but also mundane advertising plays a crucial role in providing us with models to live by. The text emphasizes how the most personal mythology often turns out to be anything but personal: it is entangled with the story economy of the times and its commercial interests.

Second, an equally important aspect of Ernaux's metanarrative autofictional mode of writing is the way it charts changes in collective narrative imagination. The narrator repeatedly refers explicitly to imagination (to "teenage imagination" [146/161], for example, or to the way in which "[t]he banlieues loomed large in the popular imagination" [141/155]). In a sense, her text is a cultural history of the transformations of public imagination. It also acknowledges that collective imagination is heterogeneous and plural. The immigrants, for example, have their own "imagination, which annoyed us insofar as it was focused elsewhere, on Algeria and Palestine" (173/192).

The narrative is permeated by reflection on how personal and collective narrative imagination constantly intersect and how individual memory is conditioned by cultural memory embedded in a specific social context. It is an organizing principle of Ernaux's autofictional writing that her life is told with an emphasis on what she remembered and what she imagined at the time. Who "Ernaux" is at a given point in her life is defined by what she remembers and dreams of at that time. At one point, she tells us, "[s]he has started to imagine herself outside of conjugal and family life" (115/126), for instance, and at another "[s]he no longer imagines herself lying on the beach or as a writer publishing her first book" $(96 / 104)$. The narrator also acknowledges that she has to imagine the book, the impersonal autobiography, before she can write it. Then, however, this project is presented as only one aspect of her everyday life and of her narrative imagination that orients her to her future: "Even more than this book the 
future is the next man who will make her dream, buy new clothes, and wait: for a letter, a phone call, a message on the answering machine" (170/188). Ernaux emphasizes that our dreams and memories (perceived as highly personal and unique) are ultimately dominated by quite banal everyday fantasies and anxieties that are largely shaped by cultural narrative models.

Third, Ernaux's autofictional writing is fundamentally relational. It acknowledges how individual life takes place within a social world in which it is part of the life of a whole generation. Much of her writing explores relationships, such as her intense love affair with a younger man while she undergoes breast cancer treatments. Ernaux's L'Usage de la photo (2005) documents this love affair through photos taken of their discarded clothes after they have had sex. In Les Années, the man "attracted her with his gentleness and his penchant for everything that makes one dream, books, music, films. This miraculous coincidence gave her a chance to triumph over death through love and eroticism" (220-221/246). Ernaux thematizes the narratively shaped intersubjective space between people, the narrative in-between that allows us to talk about certain experiences but not others. The narrator repeatedly reflects on what can be said and thought in a particular social and cultural world, experiencing as tormenting the inability to express one's thoughts and feelings:

At every moment in time, next to the things it seems natural to do and say, and next to the ones we're told to think - no less by books or ads in the Métro than by funny stories-are other things that society hushes up without knowing it is doing so. Thus it condemns to lonely suffering all the people who feel but cannot name these things. Then the silence breaks $[\ldots]$ and words burst forth, recognized at last, while underneath other silences start to form. $(97 / 105)$

In Les Années, illness, death, and aging are surrounded by silence. Through writing, Ernaux creates an intersubjective space of memory and imagination that makes it possible to fill in one of these silences through the anticipation of one's own death: "The future is replaced by a sense of urgency that torments her. She is afraid that as she ages her memory will become cloudy and silent, as it was in her first years of life, which she won't remember anymore. [...] Now's the time to give form to her future absence through writing" $(222 / 248-249)$. In connection to this intertwinement of presence and absence, she writes about "palimpsest time" 
$(223 / 249) .{ }^{5}$ This is a layered time in which the past is overwritten by the present and future: "What matters to her, on the contrary, is to seize this time that comprises her life on Earth at a given period, the time that has coursed through her, the world she has recorded merely by living" $(223 / 250)$. Such an acute sense of temporality and finitude marks her whole process of life writing.

Overall, a key affordance of Ernaux's experimental metanarrative autofictional writing is that it allows her to acknowledge how much of our existence is not a matter of action but of being acted upon. We are as much a product of what happens to us as we are centers of action and meaning that give sense and direction to our own lives. Les Années highlights the continuous dialogue between these two sides of our existence. We are socially conditioned, but we learn to become narrators of our lives who act as if we could simply choose a certain direction for our own lives and life-narrations. Yet, Les Années shows how deeply entrenched this narrative agency is in narratively constituted webs of relationships that shape what the individual, as a member of a generation, remembers and imagines.

\section{Knausgaard's Essayistic Storytelling: The Search FOR AUTHENTICITY}

An important theme in Karl Ove Knausgaard's (2009-2011) six-volume autofictional series Min kamp is the search for an authentic mode of being through a process of writing one's life. Integral to this is a search for authentic storytelling, which involves a struggle with culturally dominant narrative models he finds limiting. Telling the story of one's own life, an act of practicing narrative agency, opens up the possibility to turn from being a victim to an agent. At the same time, Knausgaard's autofictional series is shot through with a critical attitude toward narrativizing life. On the one hand, life is for him a flow of experiences, and narrative is deeply problematic insofar as it tries to stop the flow and appropriate life into a closed form. On the other hand, narrative is shown to be indispensable to being human. I argue that Knausgaard strives to find a form of fragmentary, essayistic, open-ended storytelling that deliberately avoids appropriation and closure.

The two primary ways in which Knausgaard's autofictional series contributes to narrative awareness are, first, by reflecting on the tension between life and narrative, and second, by drawing attention to, and 
critically reflecting on, cultural narratives that steer our lives, as the narrator observes in the sixth volume of the series: "We need to be alert whenever events shape themselves into narratives, for narratives belong to literature and not to life, and occurrences of the past seep into and absorb expectations of the future" $(2018,534 / 517)$. Occurrences pass quickly, but newspapers tell stories that give them a fixedness:

The event is lifted out of its physical environment and its particular moment and goes from being without continuity to becoming a part of an ongoing, so-called news. Anything that cannot be explained, any unexpected accident or catastrophe, any instance of sudden death or incomprehensible malice is gathered here in the form of small narratives, and the mere fact of their being told is sufficient to put us at ease, to assure us that order exists. $(2018,651 / 627)$

Min kamp suggests that narratives provide reassurance and a sense of control, but we should be aware of the flux of events that lies underneath the neat narratives that create a false illusion of order. An important way in which reality is ordered is through cultural narrative models.

Min kamp particularly reflects on cultural narrative models of masculinity, including models of being a father, husband, and artist. "Knausgaard" struggles with these models in trying to find his own path, which entails both a style of existence and a style of writing that he can consider authentic. He asks how he might turn his "almost inexhaustible" recollections "into a coherent narrative? And how to do so in such a way as to remain faithful to what was mine about them?" $(2018,66 / 68)$. He is largely aware of his debt to the tradition of Romanticism, which emphasizes that which is unique to each individual, but he also critically engages with this tradition by foregrounding our fundamental connectedness to other people. ${ }^{6} \mathrm{He}$ does not want to repeat the mistakes of his father; instead, he wants to be a committed, loving parent, whose children "shouldn't be afraid of their own father" $(2014 c, 248 / 246)$. I agree with Christian Refsum that, despite being criticized for individualism and egoism, "Knausgaard" strives "to find and maintain attachment, belonging, and love" $(2020,370)$. A deep commitment to his nuclear family is crucial to his sense of self; both love and writing are for him modes of renewal through which he searches for self-fulfillment and self-transformation. When caught between trying to be a good father/husband and a good writer, however, he ultimately privileges his ambitions as a writer in his struggle for authenticity. 
It is first and foremost the conventionality of everyday routines and habits that oppresses him:

perhaps it was the prefabricated nature of the days in this world I was reacting to, the rails of routine we followed, which made everything so predictable that we had to invest in entertainment to feel any hint of intensity? Every time I went out of the door I knew what was going to happen, what I was going to do. This was how it was on the micro level, I go to the supermarket and do the shopping, I go and sit down at a café with a newspaper, I fetch my children from the nursery, and this is how it was on the macro level, from the initial entry into society, the nursery, to the final exit, the old folks' home. (2014b, 75-76/67-68)

Crucial to Knausgaard's ethos - to the overall guiding beliefs and ideals that shape the narrative-is a search for authenticity characterized by the struggle of each individual to become who they are, against such obstacles as conventions, norms, and dominant narrative models. In particular, the narrator repeatedly places the singularity of what is happening to him against the generality of narrative models: "For a moment, it was as if I was entering a larger story than my own. The sons leaving home to bury their father, this was the story I suddenly found myself in" (2014a, 296/265). After a while, however, the "sensation of the great story had gone. We were not two sons, we were Yngve and Karl Ove; we were not going home but to Kristiansand; this was not a father we were burying, it was dad" (2014a, 297/266). He feels that taking up the Scandinavian model of a father who stays at home with the children takes something away from him: "When I pushed the buggy all over town and spent my days taking care of my child it was not the case that I was adding something to my life, that it became richer as a result; on the contrary, something was removed from it, part of myself, the bit relating to masculinity. [...] I squeezed myself into a mould that was so small and so constricted that I could no longer move" (2014b, 99/87). Ultimately, "Knausgaard" resists one model—a distant, authoritative father-figure like his own-only to find himself diminished by the alternative model-the modern Scandinavian father-figure, which may be conceived as more in line with a traditionally female model. Awareness of these models allows him to gain critical distance from them, but being caught between them remains a struggle. 
Knausgaard's contribution to narrative imagination is linked to his explicit interest in exploring "what is possible and what is not possible to say and do in a given day and age" $(2018,762 / 732)$. The sixth volume, for example, discusses the historical context that allowed Hitler to gain power and draws a parallel to the Utøya massacre in contemporary Norway. ${ }^{7}$ In 1910, it would not have been possible for Hitler to become a political leader, the narrator muses $(2018,765 / 734)$, but in the 1930s a world emerged in which ordinary people, "we," became supporters of the Nazi regime. He analyzes how this launched a tradition that has enabled the rise of far-right extremism across contemporary Europe. He suggests that we cannot understand the rise of Nazism unless we acknowledge what he calls the "power of the we" $(828 / 792)$, which implies that we ourselves could have been Nazis had we been born in a different time and place (see also Meretoja 2018, 217-254).

In Min kamp, narrative imagination also concerns the question of how to expand one's sense of the possible. What liberates "Knausgaard" and expands his sense of the possible is primarily art. He is trying to get hold of the singularity of who he is, under the pressure of narrative models, norms, and life trajectories forced on individuals. Linear narrative form represents conventionality for Knausgaard, which is why he struggles to give expression to what evades narrativization, and in this effort he turns to the fragmentary, essayistic form that he develops throughout his series. His search for authenticity combines an aesthetic of transiency and unfinishedness with an ethics and aesthetics of brutal honesty. Knausgaard attempts to create a narrative style that is as true to reality as possible. Tired of fiction, he wants to develop an aesthetics of truth that is animated by a hunger for reality: "The idea was to get as close as possible to my life" $(2014 \mathrm{~b}, 654 / 554) .{ }^{8}$ For him, the search for authenticity is inextricably linked to the project of writing in which he displays the secrets of his soul as scrupulously and completely as possible. He seems to think that a brutally honest narrative that reveals his life in all its contradictory, messy complexity is key to integrity and authenticity.

Knausgaard contributes to narrative imagination by developing an aesthetics of brutal honesty that lays bare the destructiveness of the grind of everyday routines and narratives with which we structure them-an aesthetic he calls the "banality of the everyday" (2012). In a way, this is for Knausgaard not only an aesthetic but also an ethos used to justify placing art above the ethical commitments of family life and community life. Ultimately, only art is sacred for him. He pushes the limits of what can be 
said and done in literature in order to turn the tedious everyday life into something meaningful that makes life worth living: "Everyday life, with its duties and routines, was something I endured, not a thing I enjoyed, nor something that was meaningful or made me happy. [...] I always longed to be away from it, and always had done. So the life I led was not my own. I tried to make it mine, this was my struggle, because of course I wanted it, but I failed, the longing for something else undermined all my efforts" $(2014 b, 75 / 67)$. Out of this failure grows the Knausgaardian narrative imaginary characterized by an oscillation between commitments to others and a search for authenticity.

In terms of dialogicality, Min kamp presents narrative as not only a matter of conventional cultural models that convey norms and stereotypical roles but also as a possibility of establishing connections with others. Narrative is for the narrator "a matter of communication, establishing community out of what was one's own" $(2018,65 / 67)$. Narrative is a process of giving meaning to the world, which is for him "not only our responsibility but also our obligation" $(2018,373 / 366)$, but this process only makes sense if we understand that language is the medium through which we enter into a dialogical relationship with others: "In the language I exist, but only if there is also a you to which the I of the speech act can relate, because if not how then should the I separate itself and find form?" $(2018,465 / 454)$. Hence, despite Knausgaard's attachment to the idea of a romantic genius searching for authenticity, he also recognizes that he is fundamentally dependent on and connected to others. One of the crucial tasks his narrator sets for himself is to explore these connections: "meaning arises out of cohesion, in the way we are connected to one another and our surroundings. This is the reason I write, trying to explore the connections of which I am a part" $(630 / 606)$. At the same time, however, he says he wrote the series in an effort to free himself "from everything that ties" (2018, 982/942). Throughout the series, Knausgaard explores this fraught relationship with our fundamental relationality. Although relationality is often seen to be characteristic of women's autobiographical writing, Knausgaard shows that it can be a key issue for male writers too.

Narrative dialogicality involves awareness of how each narrative can be told from multiple perspectives and how our individual narratives enter into dialogue with those of others. Despite Knausgaard's commitment to truth, it is evident that his narrative is an interpretation, a selection: some things are left out, others told with excruciating detail. In making such choices, he practices his power of narrative agency. Narratives always 
represent a certain perspective, and the narrator of Min kamp makes clear that the series is primarily about his perspective, his truth, his shame, and anguish. It is a largely monological project, which can be considered ethically problematic, but "Knausgaard" also metanarratively foregrounds his own status as a narrator who selects what to tell and how to tell it. In fact, the self-reflexive dimension of the series entails that Knausgaard never pretends to tell the whole truth or the only truth. He aspires to tell his truth and to acknowledge how it necessarily takes shape in dialogical relationships, and often in tension with the truths of other people.

Nevertheless, as his life is entangled with those of others, he also has to consider the cost. Brutal honesty comes at the expense of those close to him, whom he turns into material for his art. ${ }^{9}$ Hence, the series is ultimately permeated with a tension between an individualist search for authenticity and a relational sense of connectedness. Its narrative dialogicality contributes to a narrative in-between that makes it possible to verbalize shame, insecurity, and selfishness, a space that enables Knausgaard to become visible as an incomplete and imperfect person and writer in search of his own truth. He does this through essayistic, fragmentary storytelling that deliberately eschews narrative mastery and definitive answers to fundamental existential and ethical questions. His metanarrative reflections are grounded in a poetics of essayistic, explorative, fluid, and openended autofiction.

\section{Swan's Autofictional Cancer (Counter-)Narrative}

Astrid Swan's Viimeinen kirjani (My Last Book) is a genre-defying book about the author's journey to become a singer-songwriter, mother, and writer, while learning that she has incurable metastatic breast cancer. Swan's experimental narrative challenges linear narrativity and plays with the permeable border between fictionality and nonfictionality. It starts off like a fairytale: "Once upon a time there was a woman, who breast-fed her almost two-year-old, speaking child" $(2019,9) .{ }^{10}$ Swan's way of dealing explicitly with her own experience of illness makes her book a memoir. While memoir, however, is traditionally seen as a nonfiction genre, Swan employs aesthetic strategies that draw attention to the process of experimental writing and give the text a quality of literariness. For example, the chapters are numbered in an irregular fashion- $5,30,7,24,5$, indicating her age at the time of the narrated events-which emphasizes the way she writes from the middle of events that refuse to settle into a linear, coherent 
narrative. Diary excerpts are interspersed with interior monologue, reflections on the past, snapshots of the present, and anticipation of the future into a collage-like assemblage. Throughout her book, "Swan" comments on her own process of narration and on cultural models for illness narratives. As she struggles with culturally dominant narratives of fighting breast cancer, she reflects on how lives are entangled with one another through shared narrative imagination and processes of co-telling in which lives are narrated collaboratively.

In terms of the three dimensions of narrative agency, Swan's book contributes to narrative awareness particularly through its critical engagement with cultural narrative models linked to narrating illness. She looks for stories in which she would recognize herself, but finds that the available repertoire of cancer narratives is limited: "It has been difficult to find narratives that reflect me back to myself" (138). The dominant cancer narratives emphasize battle and recovery. The metaphor of war, which portrays cancer patients as fighters, has been criticized since Susan Sontag's Illness as Metaphor (1978) but continues to dominate the culturally mediated narrative imagination concerning cancer (see also Ehrenreich 2001; Bleakley 2017). The battle narrative is problematic because it turns cancer patients into either winners or losers, the implication being that those who die did not fight hard enough (see Meretoja 2021, 38).

It is significant that Swan's narrator has problems not only with the dominant narrative of fighting cancer but also with such a counternarrative as the feminist activist Audre Lorde's The Cancer Journals (1980), which is meant to be an empowering narrative that encourages breast cancer survivors to be proudly one-breasted: "I am not, after all, a valiant one-breasted warrior who carries her scars without shame. I want to camouflage" (Swan 2019, 243). She also finds problematic the normative pressure to be positive that is integral to culturally dominant narratives of illness: "Those who suggest I should look at everything a little more positively cannot fathom the form my life has taken" (254). Swan draws attention to the strong normative element of obligatory optimism. As Emilia Nielsen (2019) observes, in the culturally preferred cancer narrative one wages war on cancer with courage and optimism, as if recovery depended simply on the right attitude and enough willpower. Nielsen analyzes alternative stories, counter-narratives, that she calls disruptive breast cancer stories, and shows how they make room for a wider range of emotions in the experience of cancer. However, people rarely want to hear stories of anger or grief. Swan contributes to such disruptive 
counter-narratives by exploring complex, dark affects linked to the experience of facing terminal illness and the inevitably approaching death.

Swan's autofictional writing compellingly verbalizes aspects of both personal and collective narrative imagination. She frequently speculates on what could have been-on life trajectories that did not actualize. For example, as an exchange student in the US, she "receives a whole fastforward of what-if-life": "What if I had been born elsewhere? What if my parents had been entirely different people? What if everything that happened had happened but in a different setting?" (2019,81). Narratives are a vehicle of imagination, of imagining an elsewhere, which can be either a past elsewhere or a not-yet that could unfold one day. "Swan" tries to imagine her forebears, including her lost grandfather, an Ashkenazi Jew who had a nomadic lifestyle, but she also reflects on how weaving her family history into an imaginative narrative may grow into "a dangerous story inside of me" (52). Narratives are also a mode of reaching to the future, even beyond death. She refers to her "insatiable hunger of stories" (142), which is linked to a "fear of disappearing" (47), and suggests that stories are for her a mode of survival: "I live by stories" (46). This connects her to a literary tradition going all the way back to One Thousand and One Nights (see Meretoja 2018, 168). Survival through storytelling is connected to the need to imagine both where she comes from and where she is going.

My Last Book shows how we live at the intersection of a multitude of narratives and must deal with their tensions and contradictions: "for me both narratives are necessary and true" (68). Narrative imagination involves the ability to imagine the messiness of the narrative webs in which we are entangled. Although it is in the power of narrators to decide which versions of particular stories to tell and "what they emphasize" (60), she also acknowledges that life stories ultimately take shape through shared narrative imagination and processes of co-telling. This brings us to narrative dialogicality, which is a key aspect of My Last Book. The way Swan tells her life story emphasizes the profound relationality of our existence and the inextricable entanglement of our stories with the stories of others: "We are a million different shards in other people's stories." (147) No individual is separate from the lives of others and this entanglement of lives makes them messy and layered: "It is not a tidy operation. It's a messy chaos. My life does not dislodge from the lives of others. Neither do experiences. Everything is sedimented. We share habits, memories, trauma, genes, recipes, plans, daydreams, fears..." (30). "Swan" repeatedly 
foregrounds the connections between her stories and those of others: "Invisible filaments connect me to others, their stories and cultures" (53).

As she prepares for her own death, "Swan" works through the idea of letting go of being the protagonist of her own story and becoming, instead, a character in other people's, when she no longer exists, but lives on in the stories of those who knew her or listen to her music: "I become story. A metaphor and an evaporation. I become a character inhabiting the memories, material items and behaviors of these people, even in surprising situations. Strange entanglements-moments of presence after all" (284). Coming to terms with her own death is in many ways a process of letting go-first and foremost of control because we cannot govern our death and what happens to our loved ones afterward. This involves letting go of narrative mastery, which opens up the ability to enjoy the moment and its transience: "I take pleasure in the presence of the unknown. I deliberately enjoy that which is not in my control, of which I am not aware and cannot anticipate. This is my reason for loving the moment of waking up in the morning" (285). The process of creating a narrative in-between in which the end of her life is given meaning emerges as a process of collaborative storytelling in which she participates and which those close to her will uphold, reinterpret, and transform when she is gone.

Swan's book contributes to a narrative in-between in which it is possible to share experiences of fundamental vulnerability without being paralyzed by shame and feelings of inadequacy. It questions the dichotomy between health and illness, showing how much wellbeing and agency there can be in times of serious illness. Her metanarrative autofictional writing is thereby a contribution to the discussion on "health within illness" (Carel 2008). The concept of narrative agency provides an important new perspective in this discussion. While illness is commonly seen in terms of a radical impairment of agency, acknowledging how agency is mediated through cultural narratives allows us to appreciate both our limitations at times of good health and the agency that persists in times of illness. This approach invites us to explore how agency can be strengthened through narrative practices that cultivate narrative awareness, imagination, and dialogical relationality.

This chapter has delineated the emerging phenomenon of metanarrative autofiction that self-reflexively draws our attention to the complexities of 
having to navigate contemporary narrative environments, including critical engagement with the current storytelling boom. Through the examples linked to memory and imagination, authenticity, and illness, I have unearthed key affordances of metanarrative autofiction-particularly ways in which it reflects on culturally dominant narrative models and enriches the culturally available repertoire of narratives that can help us verbalize our experiences and imagine different life trajectories. Such autofiction explores entanglements between one's own narrative agency and narratives culturally imposed on us, and it provides critical perspectives on the ways in which cultural narrative models affect the space of possibility in which we narrate our lives and become who we are. Metanarrative autofiction is an important strand of contemporary literature globally, and it remains for future research to analyze this phenomenon through a wider selection of texts from various cultural contexts. The case studies analyzed in this chapter have shown that a focus on metanarrative autofiction as a distinct form of autofiction with specific affordances provides a new perspective on both agency and its narrative mediation. This approach has allowed us to see how contemporary metanarrative autofiction articulates the complex ways in which the cultural and social forces around us affect the narrative models through which we make sense of our own experiences and those of others, and how it can expand our sense of the possible. ${ }^{11}$

\section{Notes}

1. Metanarrative autofiction can be seen as a subcategory of autofiction, but I also see it as a subcategory of metanarrative fiction more broadly (fiction characterized by metanarrativity). I embrace the view outlined in the Introduction of this volume according to which the autofictional is not only a genre-descriptor but also "a mode, moment, and strategy." In this chapter, I focus on some of the key affordances of metanarrative autofictional modes of writing.

2. I will refer to the narrator-protagonist of her autofictional writing as "Ernaux" (the version of Ernaux that emerges from the text) and will similarly use "Knausgaard" and "Swan."

3. Aging engenders, in Les Années, a voice "marked by authority, but also by a new fragility, anxiety and fear" (Jordan 2011, 138).

4. Quotations are from the English translation (Ernaux 2017). In-text citations include references to both the translation and the original (separated by a slash). The same principle is applied in Knausgaard's case.

5. On palimpsest memory, see Silverman 2013. 
6. On the Romantic roots of the idea of authenticity, see Taylor 1991.

7. The Utøya massacre refers to the July 22, 2011, attack in which Anders Breivik, a 32-year-old Norwegian right-wing extremist, shot dead 69 people attending the summer camp of the Workers Youth League on Utøya Island.

8. My Struggle can be seen as part of the phenomenon that Shields (2010) dubbed "reality hunger."

9. In an interview (2012), Knausgaard says that in this project he "gave away" his soul and he feels "a measure of guilt" for the hurt he has caused.

10. The translations are Swan's own, based on an unfinished English translation. I am grateful to Swan for providing me with these translations.

11. Work on this chapter has been funded by the Academy of Finland project Instrumental Narratives: The Limits of Storytelling and New Story-Critical Narrative Theory (project number 314769).

\section{Works Cited}

Andrews, Molly. 2014. Narrative Imagination and Everyday Life. Oxford: Oxford University Press.

Bleakley, Alan. 2017. Thinking with Metaphors in Medicine: The State of the Art. London: Routledge.

Brockmeier, Jens. 2015. Beyond the Archive: Memory, Narrative, and the Autobiographical Process. New York: Oxford University Press.

Carel, Havi. 2008. Illness. London: Routledge.

Currie, Mark. 2014. Metafiction. London: Routledge.

Ehrenreich, Barbara. 2001. Welcome to Cancerland. Harper's Magazine, November, 43-53.

Ernaux, Annie. 2005. L'Usage de la photo. Paris: Gallimard.

2008. Les Années. Paris: Gallimard.

- 2017. The Years. Translated by Alison L. Strayer. London: Fitzcarraldo.

Fernandes, Sujatha. 2017. Curated Stories: The Uses and Misuses of Storytelling. Oxford: Oxford University Press.

Fludernik, Monika. 1996. Towards a "Natural” Narratology. London: Routledge.

- 2003. Metanarrative and Metafictional Commentary: From Metadiscursivity to Metanarration and Metafiction. Poetica 35: 1-39.

Freeman, Mark. 2010. Hindsight: The Promise and Peril of Looking Backward. New York: Oxford University Press.

Hutcheon, Linda. 1980. Narcissistic Narrative: The Metafictional Paradox. Waterloo: Wilfrid Laurier University Press.

Hyvärinen, Matti. 2008. Revisiting the Narrative Turns. Life Writing 7 (1): 69-82. Jordan, Shirley. 2011. Writing Age: Annie Ernaux’s Les Années. Forum for Modern Language Studies 47 (2): 138-149. https://doi.org/10.1093/fmls/cqq080. 
Knausgaard, Karl Ove. 2009-2011. Min kamp 1-6. Oslo: Oktober. . 2012. "I Have Given Away My Soul." Interview by Jon Henley. The Guardian, March 9, 2012. https://www.theguardian.com/lifeandstyle/2012/ mar/09/karl-ove-knausgaard-memoir-family. Accessed Apr 6, 2021.

- 2014a. A Death in the Family: My Struggle 1. London: Vintage Books.

- 2014b. A Man in Love: My Struggle 2. London: Vintage Books.

- 2014c. Boyhood Island: My Struggle 3. London: Vintage Books.

- 2018. The End: My Struggle 6. London: Harvill Secker.

Koselleck, Reinhart. 2004. Futures Past: On the Semantics of Historical Time. Translated by Keith Tribe. New York: Columbia University Press.

Lorde, Audre. 1980. The Cancer Journals. Argyle: Spinsters Ink.

Lyotard, Jean-François. 1979. La Condition postmoderne: Rapport sur la savoir. Paris: Minuit.

Mackenzie, Catriona. 2008. Introduction: Practical Identity and Narrative Agency. In Practical Identity and Narrative Agency, ed. Kim Atkins and Catriona Mackenzie, 1-28. London: Routledge.

Macrae, Andrea. 2019. Discourse Deixis in Metafiction: The Language of Metanarration, Metalepsis and Disnarration. New York: Routledge.

Mäkelä, Maria, and Hanna Meretoja. 2022. Critical Approaches to the Storytelling Boom. Poetics Today 43 (2) Do you want to remove "forthcoming"? The issue comes out in June 2022 and the issue number is 43 (2), so at this moment it is forthcoming, but if you prefer just 43 (2), that's also fine by me.

Meretoja, Hanna. 2014. The Narrative Turn in Fiction and Theory: The Crisis and Return of Storytelling from Robbe-Grillet to Tournier. Basingstoke: Palgrave Macmillan.

- 2018. The Ethics of Storytelling: Narrative Hermenentics, History, and the Possible. Oxford: Oxford University Press.

- 2021. A Dialogics of Counter-Narratives. In The Routledge Handbook of Counter-Narratives, ed. Klarissa Lueg and Marianne Wolff Lundholt, 30-42. London: Routledge.

Neumann, Birgit, and Ansgar Nünning. 2014. Metanarration and Metafiction. In The Living Handbook of Narratology, ed. Peter Hühn, Jan Christoph Meister, John Pier, and Wolf Schmid. Hamburg: Hamburg University Press. https:// www.lhn.uni-hamburg.de/node/50.html. Accessed Apr 6, 2021.

Nielsen, Emilia. 2019. Disrupting Breast Cancer Narratives: Stories of Rage and Repair. Toronto: University of Toronto Press.

Polletta, Francesca. 2006. It Was Like a Fever: Storytelling in Protest and Politics. London: University of Chicago Press.

Refsum, Christian. 2020. 'A Love Relationship Is Not a Place for Refuge, It Is The Place To Be': The Theme of Love in Karl Ove Knausgaard's Min kamp. Scandinavian Studies 92 (3): 369-389.

Ricœur, Paul. 1983. Temps et récit 1. Paris: Seuil. 
Salmon, Christian. 2010. Storytelling: Bewitching the Modern Mind. London: Verso. Shields, David. 2010. Reality Hunger: A Manifesto. New York: Vintage.

Silverman, Max. 2013. Palimpsest Memory: The Holocaust and Colonialism in French and Francophone Fiction and Film. New York \& Oxford: Berghahn.

Sontag, Susan. 1978. Illness as Metaphor. New York: Farrar, Straus \& Giroux.

Swan, Astrid. 2019. Viimeinen kirjani. Helsinki: Nemo.

Taylor, Charles. 1991. The Ethics of Authenticity. Cambridge, MA: Harvard University Press.

Theisen, Bianca. 2003. Silenced Facts: Media Montages in Contemporary Austrian Literature. Amsterdam: Rodopi.

Waugh, Patricia. 1984. Metafiction: The Theory and Practice of Self-Conscious Fiction. London: Methuen.

Open Access This chapter is licensed under the terms of the Creative Commons Attribution 4.0 International License (http://creativecommons.org/licenses/ by $/ 4.0 /$ ), which permits use, sharing, adaptation, distribution and reproduction in any medium or format, as long as you give appropriate credit to the original author(s) and the source, provide a link to the Creative Commons licence and indicate if changes were made.

The images or other third party material in this chapter are included in the chapter's Creative Commons licence, unless indicated otherwise in a credit line to the material. If material is not included in the chapter's Creative Commons licence and your intended use is not permitted by statutory regulation or exceeds the permitted use, you will need to obtain permission directly from the copyright holder.

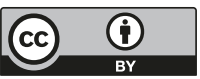

